the treatment of hay fever and whooping cough. Ephedrine B.D.H. is issued in tablets and in solution in ampoules, and as an elixir, an inhalant, a throatspray and a nasal jelly. 'Acriflavine B.D.' is a useful antiseptic for the treatment of wounds and local septic conditions. It can also be administered by mouth (as neutral acriflavine or euflavine in enteric coated tablets) or by intravenous injection. A new edition of the firm's vitamin booklet has also been prepared. It describes the uses in general practice of 'Radiostoleum' (vitamins A and D concentrate), 'Radio-Malt' (containing vitamins $A, B_{1}, B_{2}$, and $D$ ), 'Radiostol' (vitamin D) and 'Avoleum' (vitamin A). 'Radiostoleum' liquid is standardised to a 'blue' value of 500 by the Carr-Price test and contains 3,000 international units of vitamin D (calciferol) per gram. The capsules have a 'blue' value of 1,000 and each contains 1,200 vitamin $\mathrm{D}$ units. It is recommended as a preventive against infection and also in the prophylactic and curative treatment of rickets and osteomalacia and dental caries. 'Radiostol' solution is prepared from pure crystalline calciferol. It is standardised to contain 3,000 vitamin $D$ units per gram (B.P., 1932). 'Avoleum' is standardised to a 'blue' value of 1,000 .

\section{Pathology and Bacteriology at Leeds}

THe annual report for 1932 of the Department of Pathology and Bacteriology, University of Leeds, by Profs. M. J. Stewart and J. W. McLeod, recently issued, surveys the teaching and research work carried out in the laboratories. The research work includes investigations on industrial pulmonary diseases, studies in renal function, and on different cultural types of the diphtheria bacillus. In four hæmatite miners an extreme degree of pulmonary fibrosis was detected. In cancer research, Dr. Bonser has obtained results strongly suggesting that it is possible to breed a race of mice which respond very early to tumour induction by means of tar.

\section{The Ross Institute and Hospital for Tropical Diseases}

The annual report and accounts for 1932 of the Ross Institute and Hospital for Tropical Diseases, Putney Heath, S.W.15, records an increase in receipts of $£ 1,051$ compared with 1931 , and the net loss on the year's working is reduced to $£ 429$. Additional donations and annual subscriptions would be very welcome so that the work of the Institute may be extended, and income and expenditure may at least balance. Information is given respecting the activities of the Institute in various parts of the world, particularly in regard to anti-mosquito measures and malaria control, together with a summary of the research work conducted in the laboratories and elsewhere.

\section{Announcements}

THE Research Defence Society will hold its annual general meeting at the London School of Hygiene and Tropical Medicine, Keppel Street, London, W.C.1, on June 22 at 3 p.m., when the seventh Stephen Paget memorial lecture will be delivered by Major-
Gen. Sir Leonard Rogers on "The Saving in Life and Suffering, due to Medical and Veterinary Research, with special Reference to the Tropics".

Ww have received from Messrs. W. Watson and Sons the thirty-third edition of their catalogue of microscopic objects. The contents of this list, which are well classified, include a wide range of slides useful for teaching and demonstration purposes, and many that will appeal to the microscopist who desires slides of named species, for example. of diatoms, prepared for careful examination.

ANother volume of collected researches, published from the wards and laboratories of the London Hospital during 1932, has been issued by the Publications Committee (London: H. K. Lewis and Co., Ltd., 136 Gower Strest, W.C.1. 7s. 6d. net). The papers included, all of which have been published elsewhere, deal with many branches of the science and art of medicine and form a notable contribution to the subject.

Applications are invited for the following appointments, on or before the dates mentioned:--An assistant lecturer in mathematics at the University College of South Wales and Monmouthshire, Cardiff - The Registrar (June 12). A temporary assistant at the Mersey Laboratory of the Department of Scientific and Industrial Research-The Secretary, 16, Old Queen Street, Westminster, S.W.l (June 13). Two full-time lecturers in chemistry at the Poly. technic, Regent Street, London, W.1-The Director of Education (June 16). A lecturer in physiological chemistry at Guy's Hospital Medical School-The Dean, Guy's Hospital Medical School, London Bridge, S.E.I (June 19). A junior scientific otficer at the Fuel Research Station, East Greenwich-The Secretary, Department of Scientific and Industrial Research, 16, Old Queen Street, Westminster, London, S.W.l (June 19). A full time medical radiologist in the Western Infirmary and University lecturer in the University of Glasgow-J.-Jatheson Johnston, 87, Union Street, Glasgow (June 21). A professor of electrical engineering at University College, Nottingham--The Registrar (June 21). A principal of the Pontardawe Mining and Technical Institute and Junior Technical Day School--The Director of Education, County Hall, Cardiff (June 22). A lecturer in mathematies and an assistant lecturer in electrical engineering at the Manchester Municipal College of Technology-The Principal (July I). A professor of mathematics at the Auckland University College, New Zealand-The Secretary of the Universities Bureau of the British Empire, 88a, Gower Street, London, W.C.1 (Aug. 1). A mycologist in the Department of Plant Pathology at Rothamsted Experimental Station, Harpenden-The Secretary (Sept. 15). A professor of organic chemistry at the University of Liverpool--The Registrar. An assistant civil engineer and an assistant mechanical engineer for the Commissioners for the Port of RangoonSir Alexander Gibb and Partners, Queen Anne's Lodge, Westminster, S.W.1. 